\title{
The Quest for Restructuring the Nigerian Nation: Myth or Reality? The Role of Libraries in Amplifying the Debate
}

\author{
HARriet SEUn DAPO-AsaJu ${ }^{1}$
}

Oludayo John BAMgBose ${ }^{2}$

\begin{abstract}
The primary duty of library and information professionals is to render information services to their patrons. Although the information provided often shapes public opinion and could help in making informed decisions, librarians and other information professionals often steer clear of politics and the processes that lead to emergence of leaders, even though their activities could be greatly affected by the nature of those who emerge as political leaders. It is against this background that this research sought to take a look at the issue of political restructuring, which has been a burning issue within the Nigerian political space, and what roles Nigerian librarians could play in the realization of the demands of restructuring in Nigeria. This article is of the view that besides being perceived as relevant in the scheme of things in Nigeria, librarians' engagement could further positively impact on the condition of service of librarians and their public perception.
\end{abstract}

\section{INTRODUCTION}

Libraries, particularly academic libraries and those connected to institutions of higher learning, such as universities, polytechnics and colleges of education, depend largely on the support garnered from their parent institutions for survival. For public institutions, the political structure and the disposition of those at the helm of affairs determine the extent of sustenance and then the impacts that these libraries could make in terms of their services to their patrons. Therefore, the political system is of great importance to librarians even though caution is required in demonstrating their preferences, such that the actions of the librarians, particularly the librarians from public institutions, are not perceived to be politically motivated, thereby running contrary to their terms of engagement. However, suffice to state that a degree of freedom of expression is guaranteed for those in the academia to openly express their views on national issues. One of the areas that restructuring could positively affect in Nigerian libraries is in the area of funding.

${ }^{1}$ C Harriet Seun Dapo-Asaju 2019. Harriet Seun Dapo-Asaju, CLN, is Deputy University Librarian, Ajayi Crowther University, Oyo, Nigeria.

2 (C) Oludayo John Bamgbose 2019. Oludayo John Bamgbose, CLN is Law Librarian, Ajayi Crowther University, Oyo, Nigeria. 


\section{How the Concept “Restructuring” Evolved in Nigeria}

Several decades after Lord Lugard amalgamated the Northern and Southern protectorates in $1914,{ }^{3}$ and 58 years into the nation's political independence, ${ }^{4}$ there is still agitation by certain individuals and some groups of people in their desire to determine the nature of the political system in Nigeria, Africa's most populous nation. ${ }^{5}$ After many years of military dictatorship, many expected that the advent of the Presidential System of Government, which was ushered in by the 1999 Constitution (now with amendments), would actually address some of the concerns about national unity and the economic prosperity of the nation. ${ }^{6}$ But, almost two decades into the adventure, it would seem that Nigeria is still far from achieving this. In proffering solutions to this issue, many recommendations have been advanced, many of which support the concept of "restructuring," which has become one of the most popular terms in the Nigerian political milieu today. ${ }^{7}$

Although, the word "restructuring" had been within the political lexicon for the last three decades or so, there has never been any time that its demand in the Nigerian polity has been this audibly pronounced. Whether invoked as political campaign strategy ${ }^{8}$ or used as a ploy to oppose the government in power, restructuring has sparked debates from different angles. Nevertheless, it would appear that there is no consensus yet on what restructuring means. The Minister of Information, Lai Mohammed had revealed:

it is not the government that is not clear about what restructuring means, rather it is the people who are asking for restructuring who are not clear about what restructuring means. ${ }^{9}$

While Lai Mohammed's statement alluded to non-uniformity in the definition of restructuring as provided by many of its proponents, it also suggests in clear terms that the current move toward the restructuring of Nigeria is not being championed by the government, but by certain individuals and organizations who wish that the government would buy into this movement. Meanwhile, Matthew Ogih, who lampooned the state of having conflicting definitions, averred that having a proper understanding of the intended restructuring is critical to its implementation. ${ }^{10}$

Many of the definitions provided by authours and commentators only suggest areas that require restructuring. This is further attested to by Lai Mohammed:

for some, it means creation of additional states...for others, it is about moving certain items from the exclusive legislation list to the concurrent list, for some it means community policing, and for others it is about devolution of power. ${ }^{11}$

Indeed, the call for restructuring has rested within the following headlines:

\section{Devolution of Power}

It has been argued that the present political landscape has concentrated powers at the center, making the states and local government very weak. ${ }^{12}$ As a result of this quagmire, many have advocated

${ }^{3}$ Apata, Z.O. (1990) Luggard and the creation of provincial administration in Northern Nigeria, African Study Monographs, 11(3): 143-152.

4 Olanrewaju, J. S. (2015) Understanding Nigerian development crisis, Afro Asian Journal of Social Sciences, 6(1):1-16.

${ }^{5}$ Ikemitang, S. (2017) Does Nigeria really need political restructuring? Punch Newspaper. June 30, 2017. Retrieved July 15, 2018 from http://punchng.com/does-nigeria-really-need-political-restructuring/.

${ }^{6}$ Eras osita-njoku A. (2016) The Political Economy of Development in Nigeria: From the Colonial to Post Colonial, IOSR Journal of Humanities and Social Science 21(9): 9-15.

${ }^{7}$ Ogih, M. (2017) Restructuring Nigeria; meaning, reasons, problems and prospects, Info Guide. Retrieved July 14, 2018 from https://infoguidenigeria.com/restructuring-nigeria/.

${ }^{8}$ As could be seen during the last presidential election.

${ }^{9}$ Mohammed, L. (2017) What Restructuring Means to Us, Vanguard Newspaper August 30. 2017. Retrieved July 15, 2018 from https://www.vanguardngr.com/2017/08/restructuring-means-us-lai-mohammed/.

${ }^{10}$ Ibid., Ogih.

11 Ibid.

12 Osibogun A. (2019) Devolution of Power, Restructuring, Way Out of Nigeria's Quagmire. Vanguard Newspaper February 14, 2019. Retrieved February 17, 219 from https://www.vanguardngr.com/2019/01/devolution-of-power-restructuringway-out-of-nigerias-quagmire/. 
that the political structure be devolved from the center to the federating unit as against the current system, which tends towards unitary system of government. ${ }^{13}$

\section{Fiscal Federalism}

Resource control has been another burning issue. The proponent of this idea would readily cite the success story of the South West, which judiciously utilized its resources from the export of cocoa to develop its region. ${ }^{14}$ Regrettably, with the over dependence on oil, these hitherto buoyant States are now more or less begging States.

\section{Creation of Additional States}

There is agitation over the need to create additional States. The logic here is that States with large landmass may be unable to cover the needs of their residents. ${ }^{15}$ Oyo State for example is too big to be handled by an administrator. However, it is the view of the researchers that much more is required than State creation if Nigerians are going to truly enjoy the dividends of democracy.

\section{Establishment of State Police}

With the spate of killings in Nigeria and the inability of the security outfits to combat this crime, ${ }^{16}$ it has been suggested that the federal structure of the Nigerian police will be unworkable, going forward. ${ }^{17}$ The Peace Corp Bill sent to the President for presidential assent was declined. ${ }^{18}$ Many have also advanced that States should be made to have their State-level police. The merit in this argument is that it would facilitate intelligence gathering. This could also encourage the State government to provide more support to the police. However, while State police might be helpful, if other issues affecting functionality of the police are not addressed, the situation might remain unchanged. For example, if the police remain unequipped, their capacities to combat crime remain unimproved and if the wanton corruption in the police force is not squarely addressed, it is unlikely that the restructuring of the police would achieve any meaningful result. By the way, the police could become the tool for manipulations, just as State Governors have also hijacked the activities of the State Electoral Commissions across the 36 States of the Federation.

\section{Local Government Autonomy}

The experience of many local government areas in the last three years now justifies the need to restructure the local government system. While many of the States in Nigeria only waited till about one year to the end of their respective administration before conducting elections into the various councils, these 'appointed' Chairmen are still tied to the aprons of their Governors who may suspend or remove the Chairmen at any given time. Suffice to state that the rhetoric for restructuring actually dates back to about two decades ago. ${ }^{19}$ However, despite the clamour over these years, the government seem not to have paid much attention, except of course, with President Jonathan's regime which in 2014, held a National Conference (CONFAB) in which nearly 500 selected citizens, representing different parts of the country for over four months deliberated on wide ranging issues bothering on Nigeria's existence. Incidentally, this enjoyed overwhelming support by members of the CONFAB. ${ }^{20}$

${ }^{13}$ Amah, E. I. (2018) Devolution of Power to Local Government: Appraising Local Government Autonomy under Nigerian Federation, Beijing Law Review (9): 275-293; Agboola, T. O. (2016) The Challenges of State/Local Government Creation in Nigeria Critical Analysis. International Journal of Politics and Good Governance (7): 1-18.

14 Arowolo, D. (2011) Fiscal Federalism in Nigeria: Theory and Dimension, Afro Asian Journal of Social Sciences, 2(2) $1-22$.

15 Adewale S. A. (2014) Quest For State's Creation in Nigeria: A Harbinger of Development or Underdevelopment? Journal of Culture, Society and Development (4): 68-71.

${ }^{16}$ Agwanwo, D. E. (2014) State Policing and Police Efficiency in Nigeria, Research on Humanities and Social Sciences, 4 (25):165-173.

${ }^{17}$ Eme, O. I. and Anyadike, N. O. (2018) Security Challenges and the Imperatives of State Police, Review of Public Administration and Management 1(2): 203-218.

18 Jannah, C. (2018) Why Buhari should reconsider Peace Corps Bill - Emir of Daura, Dailypost Newspaper April 19, 2018. Retrieved February 17, 2019 from http:/dailypost.ng/2018/04/19/buhari-reconsider-peace-corps-bill-emir-daura/

19 Bello, A. (2017) Restructuring Nigeria: A Critical Analysis, This Day, June 11, 2017. https://www.thisdaylive.com/ index.php/2017/06/11/restructuring-nigeria-a-critical-analysis/

${ }^{20}$ Akintoye, B. (2017) What is Restructuring? The Nations, http://thenationonlineng.net/what-is-restructuring/ 
Suffice it to say that in the last three years, the agitation for restructuring has become more amplified and aided through the deployment of digital, print, and electronic media. ${ }^{21}$ The reasons for the initial neglect are threefold:

- One, some people believe that there is no guarantee that such an exercise will succeed in moving the nation forward, and that it may even be counter-productive or lead to unexpected consequences;

- Prior to 2015, the people who were calling for restructuring never gave a clear definition of what they meant by re-structuring, neither were they specific about the scope, modalities or even the timing of such an exercise;

- Up till 2015, most of the calls for restructuring had been from individuals and groups from the southern part of Nigeria, especially South-south geo-political zone. Others from the North probably think that the agitation is because the South controls the major mineral resources that constitute the bulk of Nigeria's wealth.

- It has also been alleged that the ruling party capitalized on this agitation to coast home in the electoral victory to themselves.

Shortly after the 2015 general elections and after appointments were made again, the agitation for restructuring resonated again based on the following reasons:

\section{Perceived Lop-sided Appointments}

Notwithstanding the provision of the constitution that guarantees federal character, many have alleged favoritism in the appointments into key positions in the present administration. More specifically, many have alleged that the security architecture of the nation is headed by persons from the President's geopolitical zone and religion and that on certain occasions, those appointed have family relationships with the president. This is to the extent that the Security Council meeting could be conducted entirely in Mr. President's native language. In truth, the implication of such affiliations on the security level is that it becomes extremely difficult if not impossible to sanction non-performing security personnel. It has also been argued that the appointment into the security arm has been concentrated into a particular geo-political zone.

\section{Increasing Level of Poverty}

It could be recalled that the first major problem the current administration battled with upon assumption of power was economic recession. Many jobs were lost, civil servants and pensioners denied their regular pay and the attendant consequences of job loss and general reduction in the standard of living. There seems to be agitation over wage increase and other demands. Only recently, the World Bank revealed that the economy of Nigeria has not improved despite the exit from recession. ${ }^{22}$ To many, the currently political structure and the fiscal architecture can be attributed as the main causes of increasing problems.

\section{Growing Insecurity}

The level of insecurity in Nigeria has reached a crescendo. While many of these killings are unreported, the statistics provided by International bodies such as Amnesty International and ICRC all buttress this. Amnesty International reported that not less than 168 persons were killed in the herders/farmers clashes alone in January, 2018 across Adamawa, Benue, Taraba, Ondo, and Kaduna States. ${ }^{23}$ Many have suggested that the security system could only be overhauled when there is restructuring.

\section{Campaign Strategy}

One of the hallmarks of democratic ideals is for the opposition to constantly engage the party in power through the weapon of constructive criticism. Lately, this has been an issue of debate between the nation's ruling party and main opposition party. Even though the ruling party boycotted the 2014 CONFAB, some members of

${ }^{21}$ Farayibi, A. O. (2017), The Structure of Nigeria's Restructuring Rhetorics, National Discourse NDoo2/September, 2017, Centre for Allied Research and Economic Development, Ibadan, Oyo State, Nigeria.

22 Jenna, C. (2018) World Bank Backs IMF on Poverty Rate in Nigeria, Daily Post. May 3, 2019. Retrieved July 14, 2018 from http://dailypost.ng/2018/05/03/world-bank-backs-imf-poverty-rate-nigeria/.

${ }^{23}$ Godwin, A. (2018) Amnesty International Reveals How Many Nigeria Fulani Herdsmen Killed in 2018, Daily Post, January 30, 2018. Retrieved July 12, 2018 from http://dailypost.ng/2018/01/30/amnesty-international-reveals-many-nigeriansfulani-herdsmen-killed-2018/ 
the party participated at the CONFAB ${ }^{24}$ and had even gone on ahead to set up a committee to come up with the party's position on the issue of restructuring. Only on July 1, 2018, Afenifere declared that the pan socio-political group would only throw its weight behind any candidate any aspirant who commits to restructure the nation when elected into office. ${ }^{25}$ Even though the ruling party (Action Congress of Nigeria) has actually denied the allegation the party has included this in their manifestoes, and set up a committee, which aggregated a wide range opinions from nationwide deliberations.

While there are those who are averse to the restructuring idea, some of them have posited that Nigeria has, since the First Republic, undergone a series of restructuring journeys without commensurate progress. Besides, the country has also failed to consolidate on the gains of restructuring and making a conscious effort to improve on the challenges. Therefore, they opined that those clamoring for restructuring are perhaps looking for avenues to position themselves for relevance and wait for the opportunity to milk the country dry. ${ }^{26}$

\section{Library's ACCESS to Funds IN Nigeria}

Generally, libraries require adequate funding to enable them to fulfil their obligations to the clienteles. ${ }^{27}$ However, regrettably, libraries in Nigeria are grossly underfunded to the point that many services that should be rendered free of charge are now done with fees charged on the users. ${ }^{28}$ It should be remembered that in 1993 the NUC provided that 10 percent of the recurrent budget of Federal Government-owned university be channelled to library development. This provision had, however, been jettisoned from $2001 .{ }^{29}$ Nwafor noted that while funds made available for libraries have remained constant, the exchange rate has almost rendered the budgetary allocation incapable of meeting the basic needs of the library. ${ }^{30}$ Omoba and Fabunmi (2010) further opined that limited budget, rising salaries, growing users' demand, needs to ensure sustainability of information service and products and the market forces have forced managers of libraries in Nigeria to now levy fees on the users of the library. Little wonder then that the patronage of libraries in Nigeria is seriously declining on a daily basis. ${ }^{31}$

While one may argue that the availability of other options and alternatives has led to the general reduction in the use of traditional libraries globally, ${ }^{32}$ perhaps the level of usage of Nigerian libraries might have increased beyond its present level if the libraries were able to provide for the basic needs of the users. Today, many libraries still haven't got constant power supply, ${ }^{33}$ uninterrupted internet supply ${ }^{34}$ or the basic facilities

${ }^{24}$ Idris, H. (2017) Restructuring, Fiscal Federalism, Core APC Agenda- Lawal Shuaibu, Daily Trust Newspaper August 28, 2017. Retrieved February 15, 2018 from https:/www.dailytrust.com.ng/news/politics/restructuring-fiscal-federalism-core-apcagenda-lawal-shuaibu/211831.html

${ }^{25}$ Dapa, P. (2018) We'll See Proof of Restructuring Before Endorsement- Afenifere, Punch Newspaper, July 1, 2018. http:// punchng.com/well-see-proof-of-restructuring-before-endorsement-afenifere/

26 Ibid.

${ }^{27}$ Onomeh U., Janet and Okiy, Rose B., Sources of Funds in Academic Libraries in Delta State, Nigeria (2011). Library Philosophy and Practice (e-journal). 676.

${ }^{28}$ Ishola, B. C. (2014) Funding Problems in Nigerian University Libraries: Fee Based Library and Information Services to the Rescue, Focus on Pricing Policy, Library Philosophy and Practice (e-journal). 1176.

${ }^{29}$ Ishola, B. C. (2014) Funding Problems in Nigerian University Libraries: Fee Based Library and Information Services to the Rescue, Focus on Pricing Policy, Library Philosophy and Practice (e-journal). 1176.

${ }^{30}$ Nwafor, B. U. (1990) Funding of Universities in the Third World, Third World Libraries 1(1): 25.

${ }^{31}$ Onuoha, U. D. and Subair, M. O. (2013) Undergraduates' Use of Libraries in Federal Universities in South-West Nigeria, Journal of Research \& Method in Education 3(5): 12-17; Odu J. O. (2016) User Apathy Towards Library Resources and Service: A Case of the University of Calabar Library, Calabar, Nigeria, Global Journal of Educational Research (16): $37-45$.

${ }^{32}$ Kacherki, U. and Thombare, M. J. (2010). Print vs e-journal and Information Seeking Patterns of Users: A Case Study of SPJIMR. DESIDOC Journal of Library and Information Technology, 30(1): 22-25.

${ }^{33}$ Uwaifo, S. O. (2013) Librarians in Use of Internet by University Libraries in the South-South Zone, Nigeria, International Journal of Scientific \& Technology Research. 2(3): 290-294; D. Toyin (2014). The Effects Of Electricity Power Outage on the Provision of Electronic Newspaper Services at Samuel Adegboyega University, Ogwa, Edo State, Nigeria. Library Philosophy and Practice (ejournal). 1178.

${ }^{34}$ Baro, E. E. and Asaba, J. O. (2010).Internet Connectivity in University Libraries in Nigeria: The Present State, Library Hi Tech News 9(10):13-19; Shehu, H., Urhefe, E. A. and Aworo, P. (2015). Accessibility and Utilization Of Internet Service in Nigerian Libraries, International Journal of Academic Research and Reflection 3(5): 78-98. 
required. ${ }^{35}$ Therefore libraries and librarians need to show more concern to those who govern them and change the priorities of these people. This is because, once the right set of persons are voted into power, they will align their priorities in line with the true needs of the people. Of course, also, critical segments of the society such as the library will be accorded priority.

\section{Why Involve Nigerian Librarians in the Debate for Restructuring?}

\section{Librarians are Part of the Society at Large}

Librarians are part of the larger society. Since the debate of restructuring has been on the front burner, librarians have the rights and perhaps, obligation to be involved in the debate, as the aftermath of the decision on restructuring could affect the service delivery either positively or negatively.

\section{Libraries had Better Access to Funding During Nigeria's Regional System Which Operated a Restructured Model}

In the early days of library management in Nigeria, libraries were accorded more attention. Over the years also, the resources have kept on dwindling because support to libraries is now largely affected by nationally applied shortfalls as against the previous regime, which saw the need to support education and libraries as priorities. It can be recalled that many public libraries that exist in Nigeria today were built under the regional system of government, which tilted towards a more restructured political system.

Prof. L. O. Aina, the Chief Executive Officer of the National Library of Nigeria, while lamenting on the sudden abandonment in the support to libraries in Nigeria, remarked:

Early independence we used to have mobile libraries where we take libraries to the rural areas even in the riverine areas, boats were used to take books to them. Many of these things done before have been neglected. We used to have Bendel State Library Board and it used to be one of the best library boards in Nigeria in the 60s, 70s and 80s and they ensured books were taken everywhere across the state and some states followed suit. But later on we lost focus in Nigeria, succeeding governments were not really allocating so much money to librarianship; that is why we have been having problems. ${ }^{36}$

The establishment of libraries was seen as a thing of healthy competition among the various regions. Unfortunately, many of the libraries built then are no longer functioning at their optimum level. This, therefore, calls for a return to the regional system of government where more adequate funding could be guaranteed for libraries. As a result, libraries actually need to propagate the gospel of restructuring.

\section{Librarians are Opinion Shapers}

Libraries and librarians are opinion shapers. Through various activities such as library marketing, Selective Dissemination of Information (SDI), exhibition, and other activities, libraries have the opportunity to pass on certain information to the people. It must be said that while the choice of issues to be discussed are discretionary and left within the professional competencies of the librarian in question, it is essential that this discretion is exercised in a way that promotes morally right issues for discussion and ones that will be socially beneficial to society.

${ }^{35}$ Ugwu, C. I. and Onyegiri, D. C. (2012) Management Problems of Electronic Information Resources: A Case Study of UNN Library, International Journal of Library and Information Science 5(5): 126-133.

${ }^{36}$ Bassey, B. (2018) Stakeholders Urge FG, States to Increase Budgetary Allocation to Library, Pulse newspaper April 3, 2018. Retrieved September 13, 2019 from https://www.pulse.ng/communities/student/education-stakeholders-urge-fg-states-toincrease-budgetary-allocation-to-library/f6fq5fn. 


\section{Libraries Should Actually Meet the Needs of their Users}

Libraries are further established with the obligation to render services that meet the needs of their users. These users can range from students, teachers, and researchers who have an interest in the subject of restructuring, to politicians, civil society organizations, faith-based societies, and pressure groups. Librarians are not only required to meet their information needs but, where possible, to engage in referral services or consortium building, to see how they can actualize their research aims and objectives.

\section{What Roles Can Librarians Play?}

\section{Provide Space for Discussion on Restructuring}

One of the distinctive features of libraries is the availability of space for talks, seminars, discussions, and seminars. Libraries are expected to have the facilities for these activities. As a form of encouragement to have robust discussion and engagement on restructuring, the library could volunteer space for discussion on this issue. The space can be provided to the users free of charge or at a discounted rate. ${ }^{37}$

\section{Engage in Translation Services on Restructuring}

With over 250 ethnic and linguistic groups in Nigeria, libraries could help in the translation of information on restructure in the different indigenous languages. This will help trickle down this discussion among the local people, thereby galvanizing the needed support from every strata of society. Besides interpretation in local languages, librarians can also help repackage the information in the form of braille and sounds for the sake of those with physical disabilities.

\section{Host Conferences on Restructuring to Aggregate the Views of Others}

In the last one decade, themes of library conferences have centered on topical issues relating to development. Some have revolved round the role of library in the attainment of democratic stability, millennium development goals, and sustainable development goals, among others. Restructuring can also be featured in the programs of the Nigerian Library Association (NLA). Incidentally, this is one that the national body of the NLA picks as a topic for the year, often times, the 36 State chapters will adopt the same theme with flexibility on the sub-themes.

\section{Do Selective Dissemination of Information}

Selective Dissemination of Information (SDI) is one of the key duties of libraries the world over. Libraries can actually help to develop a knowledge-base SDI on the issue of restructuring. SDI entails providing relevant information on a particular area of knowledge, often unsolicited for the purpose of teaching, learning, and research. ${ }^{38}$

\section{Partnership with Relevant Stakeholders}

Partnership is very key in achieving greater impact. In view of this, it is essential that libraries are able to identify key partners that could assist in helping to achieve their mandates. The stakeholders can be as follows:

- Academic partners such as faculty members from disciplines of political science, sociology, law, history and international studies, peace and conflict etc.

\footnotetext{
${ }^{37}$ Sometimes, the space could be rented out for the purpose of generating funds to run the activities of the library. However, the amount charged could be discounted as a form of support to the issue under discussion.

${ }^{38}$ Nkiko, C. and Iroaganachi, M. (2015) Community-Focused Selective Dissemination of Information Services for Empowering Women through Information Provision and Utilization: Center for Learning Resouces as a Catalyst for Social Change. IFLA proceedings; Ofodu, P. N. and Agim, O. A., The Place of Library and Information Services in Open and Distance Learning in Nigerian Universities (2017). Library Philosophy and Practice (e-journal). 1642.
} 
- Professional bodies such as the Nigerian Union of Journalists, ASUU, Nigerian Bar Associations, Peace and Conflict, Association of Translators, the physically challenged etc. These partners could join hands to assist libraries propagate the message. Sometimes, these partners might even be the ones to be on the front line eventually, thereby protecting the librarians from being unnecessarily exposed.

- Civil society organizations such as faith based organizations, community development associations and non-governmental organizations that seek to entrench good governance can be approached by libraries for partnerships.

- Political parties and MDAs such as the NOA can be enlightened. Since political parties provide the platform for the emergence of candidates in Nigeria, the same platform could be used to orientate the political parties on the need to adopt the restructuring issue as part of their political party manifestoes. However, this must be done with caution so that the political parties do not believe the efforts are to make one political party have advantage above others.

\section{Provide Research Guide on Restructuring}

Unlike the practise in the United States, United Kingdom and other Western nations, the creation of webbased library guides is not popular among librarians, despite the growing reliance on the use of web-based information in Nigeria. Libraries could provide a research guide on restructuring, such that anyone who seeks to have information on restructuring could use these guidelines.

\section{Form a Movement (Pressure Group)}

Librarians in Nigeria can actually move beyond the steps highlighted above in the restructuring debate to form/join movement that could enhance the speedy realization of restructuring activity. In addition to this, librarians through its umbrella body, Nigerian Library Association (NLA) could present a position paper on restructuring. NLA can also direct its members to stage nationwide promotional services on restructuring. Finally, NLA could educate and lobby its members to vote for only candidates with the manifesto to restructure Nigeria.

\section{Conclusion: Law Librarians' Invaluable Roles}

Increasingly, law libraries are under pressure to appoint legally trained law librarians across law faculties in Nigeria. ${ }^{39}$ As a result, a number of lawyers, including the authors, are now part of the field of academic law librarians in Nigeria. The implication of this change is that traditional, non-specialized academic librarians can now leverage the skills of their academic law librarian colleagues. The following are areas where law librarians can actually help:

\section{Interpretation of the Legal Provisions}

The legal provision for the current political regime is backed primarily by the Constitution ${ }^{40}$ and other legislation. It is essential that there is a proper understanding of the provisions of this legislation. It is the sound knowledge of the law that enables librarians to speak from an informed point of view. As lawyers, law librarians can help lead the debate on restructuring, education their colleagues through seminars, conferences, focus group discussion, and through other media.

${ }^{39}$ Because academic law libraries form an important component for accreditation of the entire law faculty, attention is often placed on many parameters, such as the legal qualification of the law library staff, as against the other types of law libraries. While this article argues that academic law librarians, due to their legally trained background, could assist immensely on restructuring debate, it does not in any way suggest that other law librarians should not equally contribute to the advocacy. On the contrary, some of the law librarians across the parliaments, judiciary, and courts are even closer to decision makers and might likely lobby them into buying into the idea of restructuring.

${ }^{40}$ Constitution, Federal Republic of Nigeria, 1999 (as amended). 


\section{Preparation of Legal Documents on Legal Restructuring}

Often in the process of advocacy certain official publications are produced to reflect the official position of an organization. Such documents will go a long way in reflecting the competencies of the members of the association. Law librarians, due to their backgrounds in law, could advise their colleagues on issues in such official publications.

\section{Networking with Other Stakeholders such as the Bar Association}

As stated earlier, developing partnerships is essential to maximizing impact on advocacy. In that regard, one of the most relevant associations that the body of librarians can partner with is the Nigerian Library Association. As members of the Nigerian Bar, law librarians are perhaps in the best position to facilitate the partnership. Also, law librarians, by virtue of their strategic positions working with judges, parliamentarians, and top government functionaries at the Ministry of Justice, could use their positions to gain their employers' attention, and subsequently, gain their support toward achieving restructuring in Nigeria. 